\title{
IMPLEMENTATION OF JOHN HOLLAND'S CAREER THEORY IN GUIDANCE AND COUNSELING
}

\author{
Ramtia Darma Putri ${ }^{1}$, Syska Purnamasari ${ }^{2}$ \\ Program Studi Bimbingan dan Konseling Universitas PGRI Palembang \\ E-mail: tyadhuarrma27@gmail.com, syskapurnamasari@gmail.com
}

\begin{abstract}
Abstrack
Unemployment cases should be a reference for guidance and counseling teachers (hereinafter referred to as $\mathrm{BK}$ ) to be able to participate in efforts to reduce unemployment by providing BK services in the career field. BK offers a container in the form of various materials in order to fulfill its function. One form of implementing John Holland's career theory itself can be applied in career guidance with classical information services. In its application, this theory suggests the selection of one's work is inseparable from his personality. Someone expresses himself, his interests and values through his choice of work. In addition, this theory also recognizes RIASEC personality types that are used as students' grip in determining their future careers.
\end{abstract}

Keywords: John Holland Career Theory and Guidance and Counseling

\section{PENDAHULUAN}

Perjalanan karier yang dihadapi seseorang dimulai sejak mereka memperoleh pendidikan karier di sekolah. Pada akhir masa remaja, minat pada karier seringkali menjadi sumber masalah. Beberapa siswa memiliki persepsi mengenai penghasilan yang akan diterima ketika mulai bekerja. Siswa tidak mengerti bahwa tugas, pekerjaan, dan jabatan yang diemban akan memenuhi harapan apabila tugas, pekerjaan, dan jabatan tersebut sesuai dengan diri mereka. Yusuf (2002:35) mengungkapkan bahwa seseorang yang memasuki pekerjaan berdasarkan dengan keadaan dirinya mencakup kemampuan, kecerdasan, minat, bakat, sikap, nilai-nilai, dan sifat-sifat pribadi lainnya, akan melakukan pekerjaan dengan baik karena sesuai dengan kemampuan minat, bakat, dan nilai-nilai yang dianutnya. Pekerjaan itu memberikan kepuasan bagi dirinya, dan mendorong yang bersangkutan untuk berbuat lebih baik dan produktif. 
Data BPS dalam setahun terakhir (2017-2018), pengangguran berkurang 140 ribu orang, sejalan dengan TPT yang turun menjadi 5,13 persen pada Februari 2018. Dilihat dari tingkat pendidikan, TPT untuk Sekolah Menengah Kejuruan (SMK) tertinggi diantara tingkat pendidikan lain, yaitu sebesar 8,92 persen. Dengan kata lain, ada penawaran tenaga kerja yang tidak terserap terutama pada tingkat pendidikan SMK dan DiplomaI/II/III. Tingkat Pengangguran Terbuka (TPT) adalah indikator yang dapat digunakan untuk mengukur tingkat penawaran tenaga kerja yang tidak digunakan atau tidak terserap oleh pasar kerja. TPT pada Februari 2017 sebesar 5,33 persen turun menjadi 5,13 persen pada Februari 2018 (BPS, 2018).

Fenomena di atas dapat menjadi acuan bagi guru BK/ Konselor untuk dapat mempersiapkan karier siswa secara matang yang sesuai dengan bakat, minat, dan kemampuan. Hal ini merupakan implementasi dari Undang-Undang No 20 tahun 2003 yang menjelaskan bahwa setiap sekolah wajib memperhatikan minat siswa dalam proses pendidikan bukan hanya menekankan pada kemampuan akademiknya saja.

\section{TEORI KARIER JOHN HOLLAND}

Teori bimbingan karier John Holland mencoba untuk memaparkan bagaimana siswa atau individu memilih karier yang sesuai dengan tipe, sifat, dan karakteristik psikologis (kepribadian) dengan model lingkungan yang mencakup lingkungan: realistis; intelektual; sosial; konvensional; usaha; dan artistik (Afandi, 2011). Winkel \& Hastuti (2005:634-635) menjelaskan bahwa pandangan Holland mencakup tiga ide dasar, yaitu:

a. Semua orang dapat digolongkan menurut patokan sampai berapa jauh mereka mendekati salah satu di antara enam tipe kepribadian, yaitu : Tipe Realistik (The Realistic Type), Tipe Peneliti/Pengusut (The Investigative Type), Tipe Seniman (The Artistic Type), Tipe Sosial (The Social Type), Tipe Pengusaha (The Enterprising Type), dan Tipe Orang Rutin (Conventional Type). Semakin mirip seseorang dengan salah satu di antara enam tipe itu, makin tampaklah padanya ciri-ciri dan corak perilaku yang khas untuk tipe bersangkutan.

b. Berbagai lingkungan yang di dalamnya orang hidup dan bekerja, dapat digolongkan menurut patokan sampai berapa jauh suatu lingkungan tertentu mendekati salah satu model lingkungan (a model environment), yaitu : Lingkungan Realistik (The Realistic Environment), Lingkungan Penelitian/Pengusutan (The Investigative Environment), Lingkungan Kesenian (The Artistic Environment), Lingkungan Pengusaha (The Enterprising Environment), Lingkungan Pelayanan Sosial (The Social Environment), Lingkungan Bersuasana Kegiatan Rutin (The Conventional 
Environment). Semakin mirip lingkungan tertentu dengan salah satu di antara enam model lingkungan, makin tampaklah di dalamnya corak dan suasana kehidupan yang khas untuk lingkungan bersangkutan. Masing-masing model lingkungan hidup, termasuk lingkungan okupasi, didominasi oleh : orang yang bertipe kepribadian tertentu.

c. Perpaduan antara tipe kepribadian tertentu dan model lingkungan yang sesuai menghasilkan keselarasan dan kecocokan okupasional (occupational homogeneity), sehingga seseorang dapat mengembangkan diri dalam lingkungan okupasi tertentu dan merasa puas. Perpaduan dan pencocokan antara tiap tipe kepribadian dan suatu model lingkungan memungkinkan meramalkan pilihan okupasi, keberhasilan, stabilitas seseorang dalam okupasi yang dipangku. Sebagai sebuah contoh: seseorang diketahui paling mendekati tipe sosial, akan lebih cenderung memasuki okupasi dalam lingkungan pelayanan sosial karena okupasi itu diketahui paling sesuai dengan kepribadiannya sendiri dan paling memuaskan baginya, sedangkan orang lain yang diketahui paling mendekati tipe orang rutin, akan lebih cenderung memangku okupasi dalam lingkungan yang bersuasana kegiatan rutin, seperti pegawai di kantor, resepsionis, akuntan, dan pegawai perpustakaan. Sebaliknya, orang yang memasuki lingkungan okupasi yang jauh dari tipe kepribadian yang paling khas baginya akan mengalami konflik dan tidak akan merasa puas, sehingga cenderung untuk meninggalkan lingkungan okupasi itu dan mencari lingkungan lain yang lebih cocok baginya.

\section{KELEBIHAN TEORI KARIER JOHN HOLLAND}

Para pakar psikologi vokasional mengakui bahwa teori karir Holland adalah teori yang komprehensif, karena teori tentang jabatan ini telah mewakili seluruh pola dan aspek kehidupan individu yang berkaitan dengan kajiannya tentang model tipe, sifat, dan karakteristik individu dengan enam model lingkungan yaitu : lingkungan realistik, intelektual, sosial, konvensional, usaha dan artistik (Afandi, 2011).

\section{KEKURANGAN TEORI KARIER JOHN HOLLAND}

Kelemahan dalam teori ini adalah kurang ditinjau dari proses perkembangan yang melandasi keenamtipe kepribadian dan tidak menunjukkan fase-fase tertentu dalam proses perkembangan itu, serta akumulasi rentang umur. Mengenai tahapan atau tingkatan yang akan dicapai oleh seseorang dalam bidang okupasi tertentu, Holland merujuk pada taraf inteligensi yang memungkinkan tingkat pendidikan sekolah tertentu. 
Namun perlu ditanyakan apakah masih ada faktor-faktor lain yang mempengaruhi dalam hal ini seperti taraf aspirasi seseorang (Winkel \& Hastuti, 2005:639).

\section{IMPLEMENTASI TEORI KARIER JOHN HOLLAND DALAM BIMBINGAN DAN KONSELING}

\section{Bimbingan Karier}

Winkel \& Hastuti (2013:114) menjelaskan bimbingan karier adalah bimbingan dalam mempersiapkan diri menghadapi dunia pekerjaan, dalam memilih lapangan pekerjaan atau jabatan/profesi tertentu, serta membekali diri supaya siap memangku jabatan, dan dalam menyesuaikan diri dengan berbagai tuntutan dari lapangan pekerjaan yang telah dimasuki.

\section{Layanan Informasi Klasikal}

Menurut Permendikbud Nomor 81A Tahun 2013, layanan informasi adalah layanan BK yang membantu peserta didik menerima dan memahami berbagai informasi diri, sosial, belajar, karier/jabatan, dan pendidikan lanjutan secara terarah, objektif, dan bijak. Lebih lanjut, Prayitno, Wibowo, Marjohan, Mugiarso, \& Ifdil (2013:24) menyatakan bahwa layanan informasi terarah pada pengembangan potensi, kemampuan dan prestasi belajar, peminatan dan arah karier serta kondisi pribadi yang berkarakter-cerdas, mandiri, dan mengendalikan diri. Dalam layanan informasi perlu adanya materi mengenai wawasan, arah, dan implementasi peminatan akademik dan vokasional (karier) yang menekankan pada nilai-nilai karakter dalam bekerja seperti disiplin, ulet, dan kerja keras, jujur, produktif, nilai tambah, manfaat untuk diri sendiri, orang lain, dan lingkungan, serta pengembangan potensi siswa secara optimal.

Prayitno (2012:260) mengemukakan layanan informasi bermaksud memberikan pemahaman kepada individu-individu yang berkepentingan tentang berbagai hal yang diperlukan untuk menjalani suatu tugas atau kegiatan, atau untuk menentukan arah suatu tujuan atau rencana yang dikehendaki. Dengan demikian, layanan informasi merupakan perwujudan dari fungsi pemahaman pelayanan BK. Berkaitan dengan bimbingan karier maka informasi tentang dunia pekerjaan mencakup semua data mengenai jenis-jenis pekerjaan yang ada di masyarakat, mengenai gradasi posisi dalam lingkup suatu jabatan, mengenai persyaratan tahap dan jenis pendidikan, mengenai sistem klasifikasi jabatan, dan mengenai prospek 
masa depan berkaitan dengan kebutuhan riil masyarakat akan corak pekerjaan tertentu.

\section{APA SAJA YANG PERLU DILAKUKAN ATAU DIPERSIAPKAN GURU BK/ KONSELOR}

Pemberian bimbingan dapat diberikan oleh Guru Bimbingan dan Konseling (BK) atau Konselor yang bertindak sebagai pelaksana utama penyelenggaraan bimbingan di sekolah. Prayitno (2012:52) menjelaskan konselor adalah ahli dalam pelayanan konseling dalam menyelenggarakan layanan informasi. Konselor harus menguasai sepenuhnya informasi yang menjadi isi layanan, mengenal dengan baik peserta layanan dan kebutuhannya akan informasi, dan menggunakan cara-cara yang efektif untuk melaksanakan layanan.

Layanan informasi dapat dilaksanakan secara terbuka dan langsung oleh Guru BK atau Konselor. Berbagai teknik dan media yang bervariasi dapat digunakan secara klasikal maupun kelompok. Tohirin (2011:149) menjelaskan beberapa teknik yang dapat digunakan pada pelaksanaan layanan informasi yaitu sebagai berikut.

1) Ceramah, tanya jawab, dan diskusi

Teknik ini paling umum digunakan dalam penyampaian informasi dalam berbagai kegiatan termasuk pelayanan BK. Melalui teknik ini, para peserta mendengarkan atau menerima ceramah dari Guru BK atau Konselor, selanjutnya diikuti dengan tanya jawab, dan untuk pendalamannya dilakukan diskusi.

2) Melalui media

Penyampaian informasi bisa dilakukan melalui media tertentu seperti alat peraga, media tertulis, media gambar, poster, dan media elektronik seperti radio, tape recorder, film, televisi, internet, dan lain-lain. Dengan kata lain media yang dimaksud di sini berupa media elektronik ataupun media nonelektronik.

3) Acara khusus

Layanan informasi melalui acara ini dilakukan berkenaan dengan acara khusus yang diadakan di sekolah, misalnya "Hari tanpa Asap Rokok", "Hari Kebersihan Lingkungan Hidup", dan lain sebagainya. Dalam acara tersebut, disampaikan berbagai informasi berkaitan dengan peringatan hari tersebut dan dilakukan berbagai kegiatan yang terkait yang diikuti oleh sebagian atau seluruh siswa di sekolah di mana kegiatan itu dilaksanakan.

4) Narasumber 
Layanan informasi juga dapat dilaksanakan kepada peserta layanan dengan mengundang narasumber. Misalnya informasi tentang obat-obat terlarang, psikotropika, dan narkoba, maka narasumber yang dapat diundang berasal dari Dinas Kesehatan, Kepolisian, dan lain-lain. Untuk itu perlu didatangkan pihak lain yang mengetahuinya berdasarkan informasi yang akan diberikan.

Pelaksanaan layanan informasi dapat dilakukan dalam beberapa tahapan. Tohirin (2011:152) menjelaskan beberapa hal yang perlu dilakukan dalam pelaksanaan layanan informasi, yaitu sebagai berikut.

1) Perencanaan yang mencakup kegiatan: (a) identifikasi kebutuhan akan informasi bagi calon peserta layanan, (b) menetapkan materi informasi sebagai isi layanan, (c) menetapkan subjek sasaran layanan, (d) menetapkan narasumer, (e) menyiapkan prosedur, perangkat, dan media layanan, serta (f) menyiapkan kelengkapan administrasi.

2) Pelaksanaan yang mencakup kegiatan: (a) mengorganisasikan kegiatan layanan, (b) mengaktifkan peserta layanan, dan (c) mengoptimalkan penggunaan metode dan media.

3) Evaluasi yang mencakup kegiatan: (a) menetapkan materi evaluasi, (b) menetapkan prosedur evaluasi, (c) menyusun instrumen evaluasi, (d) mengaplikasikan instrumen evaluasi, dan (e) mengolah hasil aplikasi instrumentasi.

4) Analisis hasil evaluasi yang mencakup kegiatan: (a) menetapkan norma atau standar evaluasi, (b) melakukan analisis, dan (c) menafsirkan hasil analisis.

5) Tindak lanjut yang mencakup kegiatan: (a) menetapkan jenis dan arah tindak lanjut, (b) mengomunikasikan rencana tindak lanjut kepada pihak terkait, dan (c) melaksanakan rencana tindak lanjut.

6) Pelaporan yang mencakup kegiatan: (a) menyusun laporan layanan informasi, (b) menyampaikan laporan kepada pihak terkait, dan (c) mendokumentasikan laporan.

Demi terlaksananya kegiatan layanan informasi secara efektif dan berkelanjutan, sebaiknya Guru BK atau Konselor mempersiapkan program harian format klasikal secara lengkap dan sebaik-baiknya dalam bentu rencana pelaksanaan Layanan (RPL), sebagai salah satu tanggung jawab Guru BK atau Konselor tersebut (Putri, 2016). Selanjutnya, diharapkan dengan optimalnya pemberian layanan informasu oleh guru BK Konselor, peserta didik terdorong untuk menemukan dan mentransformasikan informasi tersebut secara kompleks, mengecek informasi yang baru berdasarkan pengetahuan yang sudah ada, dan melakukan pengembangan menjadi informasi baru sesuai dengan kemampuan yang dimiliki. 


\section{PENUTUP}

Pakar psikologi vokasional berpendapat bahwa teori karier John Holland merupakan teori yang paling memenuhi kriteria pilihan karier. Hal ini didasarkan pada perhitungan pola lingkungan dan aspek kepribadian yang dimiliki oleh individu. Pernyataan ini menjadi tugas guru BK/ Konselor untuk memfasilitasi peserta didik menentukan kariernya berdasarkan bakat, minat, dan kepribadian yang dimilikinya. Guru BK/ Konselor perlu mempersiapkan hal-hal yang berkaitan dengan pemberian layanan informasi dalam bidang karier bagi peserta didik, sehingga pilihan karier yang akan dibuat oleh peserta didik memiliki kecocokan dengan dirinya.

\section{DAFTAR RUJUKAN}

Afandi, M. (2011). "Tipe Kepribadian dan Model Lingkungan dalam Perspektif Bimbingan Karier John Holland”. Jurnal Sosial Budaya, Vol. 8 No. 01, Januari-Juni 2011.

Badan Pusat Statistik (BPS). (2018). Keadaan Ketenagakerjaan di Indonesia (2018). Berita Resmi Statistik, No. 42/05/Th. XXI, 07 Mei 2018. (Online), (https://www.bps.go.id/pressrelease/2018/05/07/1484/februari-2018--tingkatpengangguran-terbuka--tpt--sebesar-5-13-persen--rata-rata-upah-buruh-perbulan-sebesar-2-65-juta-rupiah.html, diakses 4 Januari 2019).

Permendikbud Nomor 81 A Tentang Implementasi Kurikulum.

Prayitno, Wibowo, M.E., Marjohan., Mugiarso, H., \& Ifdil. (2013). Pembelajaran Melalui Pelayanan BK di Satuan Pendidikan. Padang: UNP.

Prayitno. (2012). Seri Panduan Layanan dan Kegiatan Pendukung Konseling. Padang: UNP Press.

Putri, R.D. (2016). "Efektivitas Layanan Informasi dengan Pembelajaran Kontekstual dalam Meningkatkan Arah Perencanaan Karier Siswa SMK". Tesis tidak diterbitkan. Padang: Prodi S2 BK FIP UNP.

Putri, R.D., \& Ramadhani, E. (2017). "Implementasi Pembelajaran Kontekstual dalam Bimbingan dan Konseling". Prosiding Dosen Universitas PGRI Palembang, Edisi 18 Tahun 2018.

Tohirin. (2011). Bimbingan dan Konseling di Sekolah dan Madrasah Berbasis Integrasi. Jakarta: Rajagrafindo Persada.

Winkel, W.S., \& Hastuti, M.M.S. (2005). Bimbingan dan Konseling di Institusi Pendidikan. Jakarta: Grasindo.

Winkel, W.S., \& Hastuti, M.M.S. (2013). Bimbingan dan Konseling di Institusi Pendidikan. Jakarta: Grasindo.

Yusuf, A.M. (2002). Kiat Sukses dalam Karier. Padang: Ghalia Indonesia. 